\title{
Development of mice expressing a single D-type cyclin
}

\author{
Maria A. Ciemerych,, ${ }^{1,6}$ Anna M. Kenney, ${ }^{2}$ Ewa Sicinska, ${ }^{1,3}$ Ilona Kalaszczynska, ${ }^{1,6}$ \\ Roderick T. Bronson, ${ }^{4}$ David H. Rowitch, ${ }^{2}$ Humphrey Gardner, ${ }^{5}$ and Piotr Sicinski ${ }^{1,7}$ \\ ${ }^{1}$ Department of Cancer Biology, Dana-Farber Cancer Institute and Department of Pathology, Harvard Medical School, \\ Boston, Massachusetts 02115, USA; ${ }^{2}$ Department of Pediatric Oncology, Dana-Farber Cancer Institute and Harvard Medical \\ School, Boston, Massachusetts 02115, USA; ${ }^{3}$ Department of Pathology, Brigham and Women's Hospital, Harvard Medical \\ School, Boston, Massachusetts 02115, USA; ${ }^{4}$ Tufts University School of Veterinary Medicine, North Grafton, Massachusetts \\ 01536, USA; ${ }^{5}$ Biogen, Cambridge, Massachusetts 02142, USA
}

D-cyclins (cyclins D1, D2, and D3) are components of the core cell cycle machinery. To directly test the ability of each D-cyclin to drive development of various lineages, we generated mice expressing only cyclin D1, or only cyclin D2, or only cyclin D3. We found that these "single-cyclin" embryos develop normally until late gestation. Our analyses revealed that in single-cyclin embryos, the tissue-specific expression pattern of D-cyclins was lost. Instead, mutant embryos ubiquitously expressed the remaining D-cyclin. These findings suggest that the functions of the three D-cyclins are largely exchangeable at this stage. Later in life, single-cyclin mice displayed focused abnormalities, resulting in premature mortality. "Cyclin D1-only" mice developed severe megaloblastic anemia, "cyclin D2-only" mice presented neurological abnormalities, and "cyclin D3-only" mice lacked normal cerebella. Analyses of the affected tissues revealed that these compartments failed to sufficiently up-regulate the remaining, intact D-cyclin. In particular, we found that in cerebellar granule neuron precursors, the $\mathrm{N}$-myc transcription factor communicates with the cell cycle machinery via cyclins D1 and D2, but not D3, explaining the inability of D3-only mice to up-regulate cyclin D3 in this compartment. Hence, the requirement for a particular cyclin in a given tissue is likely caused by specific transcription factors, rather than by unique properties of cyclins.

[Keywords: Cell cycle; D-cyclins; mouse development; cell proliferation]

Received July 15, 2002; revised version accepted October 25, 2002.

The key components of the core cell cycle machinery are proteins termed D-type cyclins (Sherr and Roberts 1999). Three D-cyclins-cyclin D1, cyclin D2, and cyclin D3operate in mammalian cells. The three proteins are encoded by separate genes, but show significant amino acid similarity $(50 \%-60 \%$ identity throughout the coding region; Inaba et al. 1992; Xiong et al. 1992). The levels of D-cyclins are controlled largely by the extracellular environment. Thus, D-cyclins are induced by mitogens, and their levels decline when mitogens are removed or when antimitogens are added (Matsushime et al. 1991). For these reasons, D-cyclins are regarded as sensors of the extracellular environment that link the mitogenic pathways to the core cell cycle machinery. Once induced, D-cyclins associate with partner cyclin-dependent kinases CDK4 and CDK6 and drive phosphorylation and subsequent inactivation of the retinoblastoma

\footnotetext{
${ }^{6}$ Present address: Department of Embryology, Institute of Zoology, University of Warsaw, Miecznikowa 1, 02-096 Warsaw, Poland. ${ }^{7}$ Corresponding author.

E-MAIL peter_sicinski@dfci.harvard.edu; FAX (617) 632-5006. Article and publication are at http://www.genesdev.org/cgi/doi/10.1101/ gad.1023602.
}

tumor suppressor gene product, $\mathrm{pRB}$, and pRB-related proteins p107 and p130 (Matsushime et al. 1992, 1994; Bates et al. 1994; Meyerson and Harlow 1994). This, in turn, causes release or derepression of the E2F transcription factors and allows entry of cells into the $S$ phase (Adams 2001). Ectopic expression of D-cyclins' inhibitor, p16 ${ }^{\text {INK4a }}$, was shown to block the proliferation of several cell types, underscoring a critical, essential function for D-cyclins in cell cycle progression (Lukas et al. 1995a; Ortega et al. 2002).

During mouse development, the three D-cyclins are expressed in a dynamic and highly orchestrated fashion, often in mutually exclusive cell types. For example, a rapid switch from cyclin D1 to cyclin D3 expression takes place during early differentiation of extraembryonic mesoderm (Wianny et al. 1998). Within the early embryo, cyclins D1 and D2 display opposite, highly specific expression patterns in the developing hindbrain, cyclin D1 being expressed in rhombomeres $r 4, r 6$, and $r 7$, whereas cyclin D2 is expressed only in $\mathrm{r} 3$ and $\mathrm{r} 5$ (Wianny et al. 1998). This unique pattern of D-cyclin expression is also seen at later stages of embryo development. For instance, in certain mesenchymal-epithelial interactions, cyclin D1 is expressed exclusively in the mesenchymal 
compartment, whereas cyclin D2 is present only in the juxtaposed epithelium (Aguzzi et al. 1996). In the developing skin, cyclin D1 is present in keratinocytes and absent from developing hair follicles, whereas the converse is true for cyclin D2 (Aguzzi et al. 1996). Within the developing nervous system, cyclins D1 and D2 are expressed in distinct proliferating compartments (Aguzzi et al. 1996). In some stratified squamous epithelia and in columnar gastrointestinal epithelium, cyclin D1 localizes to the proliferative layers, whereas cyclin D3 is present in the adjacent compartments where differentiation takes place (Bartkova et al. 1998). Yet other compartments express combinations of two or even all three Dtype cyclins (Tam et al. 1994; Lukas et al. 1995b; Bartkova et al. 1998). This specific, often mutually exclusive pattern of D-cyclin expression is also preserved in several organs of the adult animals (Ravnik et al. 1995; Robker and Richards 1998).

In addition to their growth-promoting functions, Dcyclins were suggested to play unique, nonredundant roles in promoting cell differentiation of specific cellular compartments. For instance, the role for cyclin D3 in muscle differentiation is suggested by the observation that this cyclin is dramatically induced (>20-fold) when myoblasts exit the cell cycle and fuse to form myotubes. High levels of cyclin D3 persist in differentiated, quiescent myotubes. In stark contrast, the levels of cyclin D1 and D2 decline, consistent with the exit from the active cell cycle (Rao et al. 1994; Kiess et al. 1995; Skapek et al. 1995). Collectively, these observations suggest that each of the three D-cyclins may play unique, tissue-specific functions.

To elucidate in vivo functions for the three D-cyclins in different lineages, we and others previously generated mouse strains lacking each of the D-cyclin genes (Fantl et al. 1995; Sicinski et al. 1995, 1996; E. Sicinska and P. Sicinski, in prep.). We found that these knockout mice showed narrow, very restricted developmental abnormalities. Thus, cyclin D1-deficient mice displayed reduced body size, a spastic leg-clasping reflex, and some premature mortality within the first 3 wk of life, which we interpreted as an indication of the developmental abnormalities within the nervous system. Moreover, cyclin D1-deficient mice displayed severely hypoplastic retinas and pregnancy-insensitive mammary glands (Fantl et al. 1995; Sicinski et al. 1995). Cyclin D2-deficient females are sterile, owing to the inability of the ovarian granulosa cells to proliferate normally in response to the follicle-stimulating hormone (FSH), and cyclin D2 $2^{-/-}$males, although fertile, display hypoplastic testes (Sicinski et al. 1996). Furthermore, cyclin D2-deficient animals show impaired proliferation of peripheral B-lymphocytes (Lam et al. 2000; Solvason et al. 2000) and mild cerebellar abnormalities (Huard et al. 1999). Cyclin D3-deficient mice, in turn, are also viable, and display lymphoid abnormalities (E. Sicinska and P. Sicinski, in prep.).

These single-knockout experiments are illuminating, but their analyses are greatly confounded by the presence of two remaining, intact D-cyclins, which may compen- sate for the ablated protein. We decided to reduce this complexity by creating mouse strains expressing only a single D-type cyclin. In doing so, we hoped to be able to directly test which proliferative and developmental functions can be executed solely by cyclin D1, D2, or D3.

\section{Results}

Generation of single-cyclin mice

To obtain mice expressing a single D-cyclin ("single-cyclin" mice), we took advantage of cyclin $\mathrm{D} 1^{-/-}, \mathrm{D} 2^{-/-}$, or $\mathrm{D}^{-/-}$deficient animals, which we previously generated (Sicinski et al. 1995, 1996). By crossing these mice, we obtained double heterozygous $\left(\mathrm{D}^{+/-} \mathrm{D} 2^{+/-}, \mathrm{D}^{+/-} \mathrm{D}^{+/-}\right.$, or $\left.\mathrm{D} 2^{+/-} \mathrm{D}^{+/-}\right)$or heterozygous/knockout $\left(\mathrm{D}^{+/-} \mathrm{D} 2^{-/-}\right.$, $\mathrm{D}^{+/-} \mathrm{D} 3^{-/-}$, or $\left.\mathrm{D} 2^{+/-} \mathrm{D}^{-/-}\right)$animals. The double heterozygous animals were indistinguishable from the wildtype littermates, whereas heterozygous/knockout mice displayed phenotypic abnormalities characteristic of individual single-knockout strains (data not shown). Successive crosses of these mice yielded mice expressing only cyclin D1 (double-knockout cyclin D2 $2^{-/-} \mathrm{D} 3^{-/-}$, , only cyclin D2 (double-knockout cyclin $\mathrm{D} 1^{-/-} \mathrm{D} 3^{-/-}$), or only cyclin D3 (double-knockout cyclin D1 $1^{-/-} \mathrm{D} 2^{-/-}$) animals.

\section{Analyses of single-cyclin embryos}

We first collected single-cyclin embryos and analyzed their development at embryonic day 13.5 (E13.5). At this point, the primary structures of all major organs are well established and easily discernible. Unexpectedly, we found that the single-cyclin embryos were indistinguishable from control littermates. Detailed histopathological examinations revealed essentially normal morphogenesis in all tissues (data not shown). Consistent with these observations, we found that the bromodeoxyuridine (BrdU) incorporation pattern in single-cyclin embryos was virtually identical to that seen in wildtype embryos, revealing normal proliferation rates (Fig. $1 \mathrm{~A}-\mathrm{C})$.

To understand the molecular basis of this apparently normal development in single-cyclin embryos, we determined the expression pattern of the D-type cyclins in mutant embryos and compared it with that seen in wildtype littermates. These analyses revealed that a cyclin that is normally not expressed in a particular compartment (or expressed at low levels) becomes reactivated in the corresponding compartment of single-cyclin embryos. For instance, developing wild-type livers express only trace levels of cyclin D2, whereas in livers of cyclin $\mathrm{D}^{-1-} \mathrm{D} 3^{-/-}$mice, cyclin D2 becomes greatly up-regulated (Fig. 2A). Likewise, developing spleens express cyclins D2 and D3, but only trace levels of cyclin D1, whereas cyclin D1 is greatly up-regulated in this organ in cyclin D2 $2^{-/-}$D3 ${ }^{-/-}$embryos (Fig. 2A). As a consequence, in single-cyclin embryos the tissue-specific expression pattern of D-cyclins is lost. Instead, single-cyclin embryos ubiquitously express the remaining, intact D-cyc- 


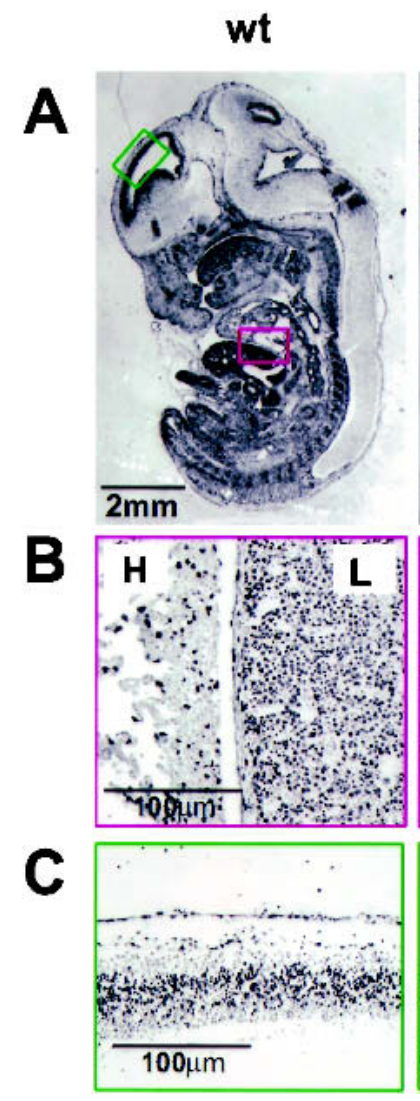

\section{D1-I-D2-I-}
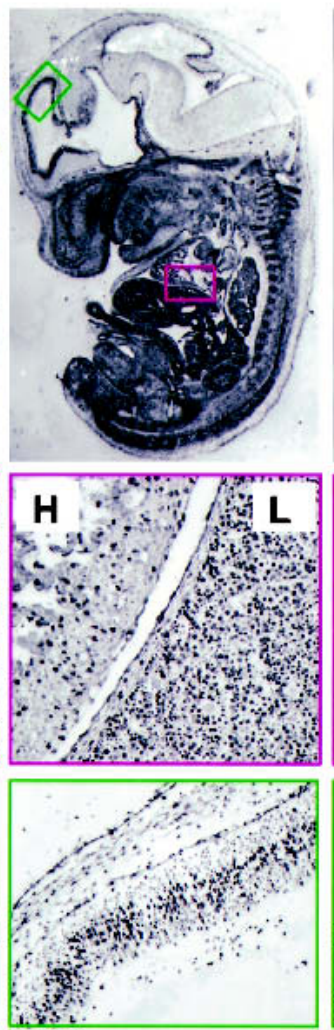

D1-/-D3-\%
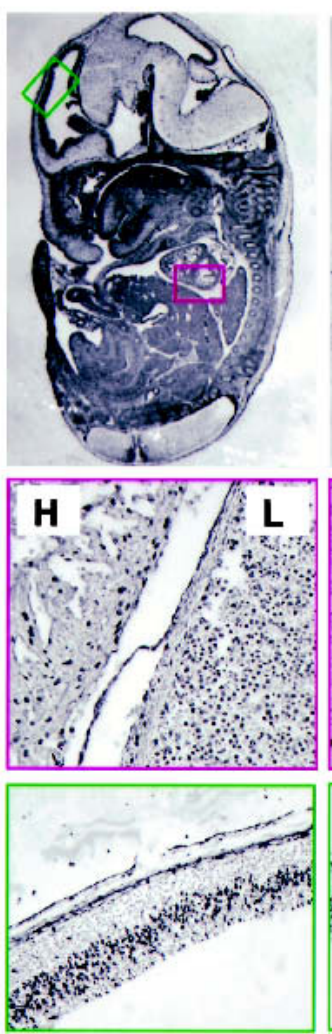

D2-I-D3-I-
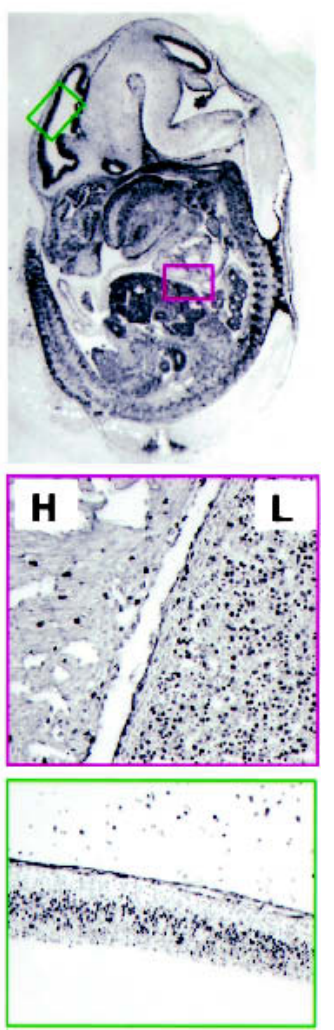

Figure 1. Bromodeoxyuridine (BrdU) incorporation in wild-type and single-cyclin embryos at E13.5. Pregnant females were injected with a single dose of BrdU, and the embryos were collected $1 \mathrm{~h}$ later and processed for histology. (A) Sagittal sections of the entire embryos were stained with an anti-BrdU antibody. $(B)$ Higher magnification showing normal BrdU incorporation rate in single-cyclin hearts $(\mathrm{H})$ and livers $(\mathrm{L})$. $(C)$ Higher magnification showing normal BrdU incorporation rate in single-cyclin roofs of neopalial cortex.

lin in all tissues (Fig. 2B). Collectively, these findings suggest that each of the D-cyclins, when ubiquitously expressed, can afford normal proliferation of the developing embryo. This, in turn, indicates that the functions of the three D-cyclins, at least until this point of development, are exchangeable. Alternatively, the development of certain tissues may occur in a cyclin D-independent fashion.

In addition to activating CDK4 and CDK6 kinases, Dcyclins were shown to titrate the p2 $7^{\text {Kip1 }}$ cell cycle inhibitor from cyclin E-CDK2 complexes to cyclin D-CDK complexes, thereby triggering the activation of the cyclin E-CDK2 holoenzyme (Cheng et al. 1999; Sherr and Roberts 1999; Tsutsui et al. 1999). For this reason, we hypothesized that in addition to up-regulating the remaining D-cyclin, single-cyclin embryos might also reduce the levels of $\mathrm{p} 27^{\mathrm{Kip} 1}$ to ensure proper activation of the cyclin E-CDK2 kinase. To address this issue, we compared the levels of $\mathrm{p} 27^{\mathrm{Kip} 1}$ in different organs of wild-type and single-cyclin embryos. Consistent with our hypothesis, we observed marked down-regulation of $\mathrm{p} 27^{\mathrm{Kip} 1}$ protein in several organs of single-cyclin embryos (Fig. 2C). Importantly, our semiquantitative reverse-transcription-PCR analyses revealed similar levels of $\mathrm{p} 27^{\mathrm{Kip} 1}$ transcripts in wild-type and mutant tissues (data not shown), indicating that down-regulation of p $27^{\mathrm{Kip} 1}$ protein levels occurs at the posttranscriptional level.

The down-regulation of $\mathrm{p} 27^{\mathrm{Kip} 1}$ might have caused nonphysiologic up-regulation of CDK2-associated kinase, thereby bypassing the requirement for D-cyclins in cell-cycle progression. To address this possibility, we prepared lysates from wild-type and single-cyclin embryos, immunoprecipitated CDK2, and determined associated kinase activity using histone $\mathrm{H} 1$ as a substrate. These analyses revealed normal CDK2-associated kinase activity in single-cyclin embryos (Fig. 2D). Collectively, we interpret these findings as an indication that the ubiquitous, global expression of the remaining D-cyclin, together with down-regulation of $\mathrm{p} 27^{\text {Kip } 1}$, affords normal activation of cyclin E-CDK2 kinase and allows normal proliferation of cells in single-cyclin embryos.

\section{Phenotypes of single-cyclin mice}

We next turned our attention to the appearance of singlecyclin animals at later stages of embryonal development and in postnatal life. First, we analyzed the development of mice expressing only cyclin $\mathrm{D} 1$ (cyclin $\mathrm{D} 2^{-/-} \mathrm{D} 3^{-/-}$ animals). No live pups were recovered at day 1 of post- 
B

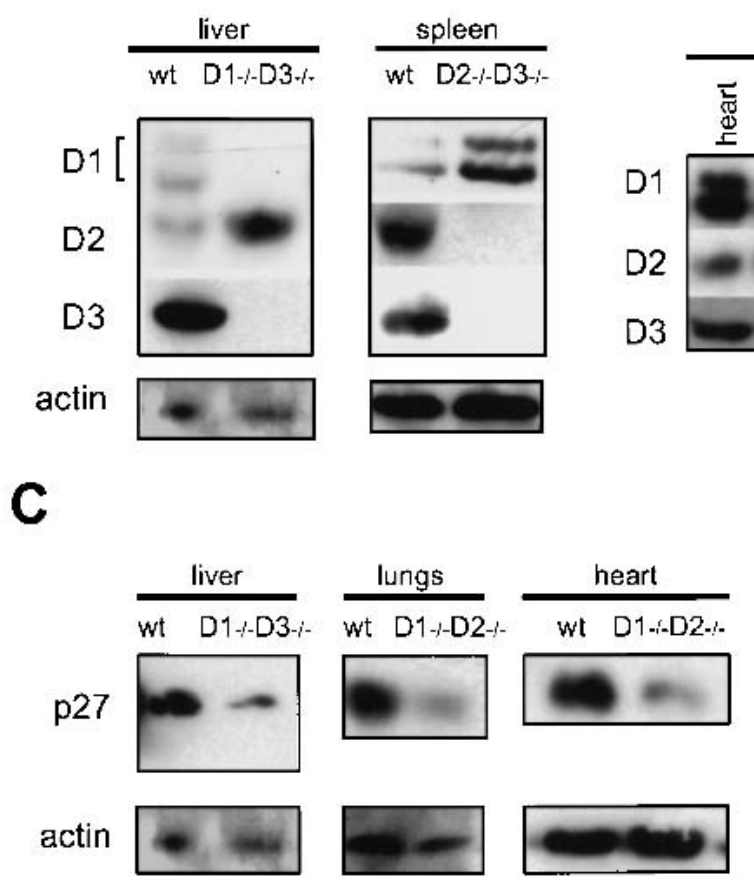

D

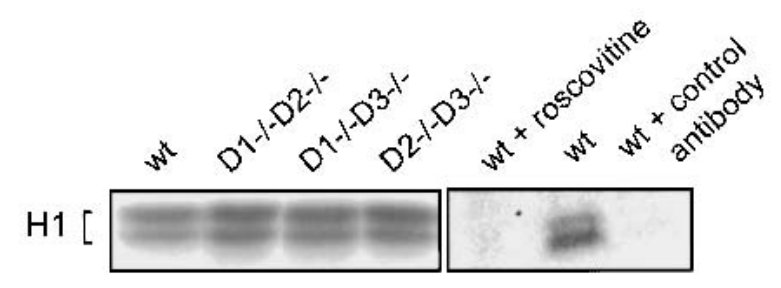

Figure 2. Molecular analyses of single-cyclin embryos. $(A-C)$ Protein lysates were prepared from indicated organs of mutant or wild-type embryos and subjected to Western blotting. $(A)$ Comparison of the levels of particular D-cyclins between wild-type and single-cyclin embryos. In mutant embryos, the remaining, intact D-cyclin becomes up-regulated in compartments in which it is normally not expressed or is expressed at low levels. Developing livers and spleens were collected at E13.5 and E16.5, respectively. (B) Expression pattern of the D-type cyclins in wild-type and single-cyclin embryos. Wild-type, cyclin $\mathrm{D} 1^{-/-} \mathrm{D} 2^{-/-}$, and $\mathrm{D} 1^{-/-} \mathrm{D} 3^{-/-}$ embryos were collected at E18.5, whereas cyclin D2 $2^{-/-} \mathrm{D} 3^{-/-}$embryos were collected at E16.5. (C) The levels of $\mathrm{p} 27^{\mathrm{Kip} 1} \mathrm{protein}$ in organs dissected from wild-type and single-cyclin embryos. Livers were collected at E13.5, hearts and lungs at E18.5. The blots were probed with an anti-actin antibody to ensure equal loading. (D) CDK2-associated kinase activity in single-cyclin embryos. Lysates were prepared from E13.5 embryos of the indicated genotypes. CDK2 was immunoprecipitated and kinase assays were performed using histone $\mathrm{Hl}$ as a substrate. For control, wild-type lysates were either treated with $15 \mu \mathrm{M}$ roscovitine (wt + roscovitine) or were subjected to immunoprecipitation with unrelated, control anti-progesterone receptor antibody (wt + control antibody).

natal life (P1). Analyses of embryos at different stages of development revealed that cyclin D1-only embryos died toward the end of pregnancy, with the longest survival at E18.5 (Fig. 3A; Table 1).

Histopathological analyses of mutant embryos revealed essentially normal morphogenesis in all tissues except for the developing livers. Analyses of this compartment demonstrated severely reduced numbers of immature erythroid cells in cyclin D1-only livers at E16.5 (Fig. 3B,C). Because fetal livers are the major source of erythropoiesis at this stage of development, it was likely that observed abnormalities would result in a profound anemia. To address this possibility, we collected peripheral blood from mutant embryos and analyzed the numbers and appearance of the mature (enucleated) erythrocytes. We found that the number of red blood cells in the peripheral blood of mutant mice was reduced nearly fourfold $\left(6.5 \times 10^{5} \pm 1.6 \times 10^{5} / \mu \mathrm{L}, \mathrm{n}=6\right.$, in $\mathrm{D}^{-/-} \mathrm{D}^{-/-}$ mice vs. $23.9 \times 10^{5} \pm 2.1 \times 10^{5} / \mu \mathrm{L}, \mathrm{n}=7$, in control embryos), revealing that cyclin D1-only animals developed a severe anemia. Significantly, the size of enucleated red blood cells in the peripheral blood was greatly increased (Fig. 3D), a megaloblastic feature seen in anemias caused by impaired division of erythroid precursors. Moreover, several immature forms of red cell lineage were often observed in the peripheral blood of mutant animals (data not shown), again pointing to impaired generation of red blood cells. These findings, together with apparently normal development of all other organs (data not shown), suggested that severe anemia was a cause of death.

Next, we analyzed the development of mice expressing only cyclin $\mathrm{D} 2$ (cyclin $\mathrm{D}^{-/-} \mathrm{D}^{-/-}$animals). We found that these cyclin D2-only mice were born with nearly expected frequency (Fig. 4A; Table 1). A great majority of animals died by the end of the first day of life. Close examination of cyclin D2-only pups revealed that they were unable to suckle and presented empty stomachs. Moreover, the physiologic content of the neonatal gastrointestinal tract, meconium, was often found in the lungs of dead mutants (Fig. 4D,E), suggesting an acute asphyxiation caused by meconium aspiration syndrome (Greenough 1995). This nature of phenotypic abnormalities points to abnormal neurological reflexes as a cause of death.

A small fraction of cyclin D2-only mice escaped perinatal death and survived up to 2 mo of life (Table 1). 


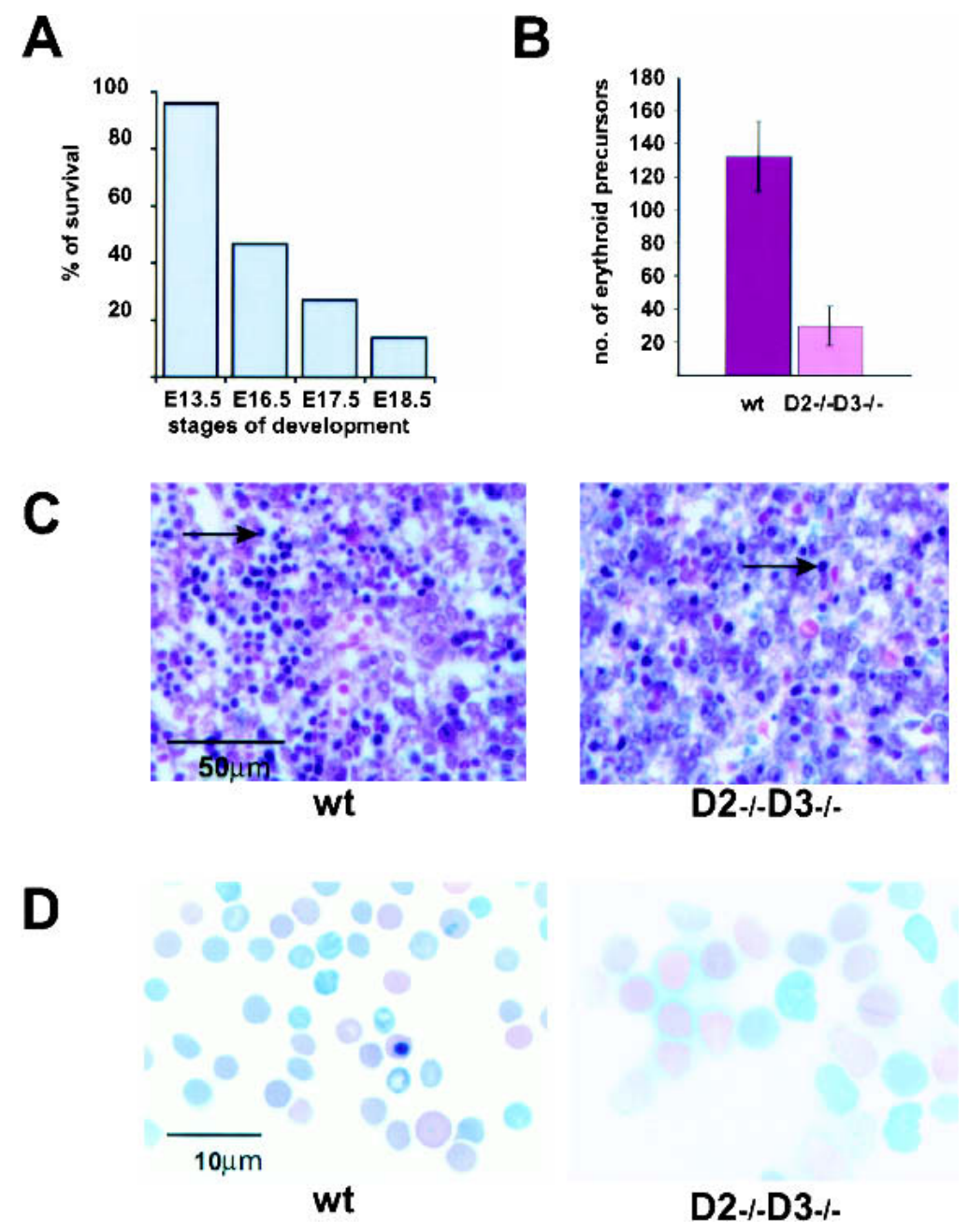

Figure 3. Phenotype of cyclin D1-only /cyclin $\mathrm{D} 2^{-/-} \mathrm{D}^{-/-}$) mice. (A) A graph showing survival rate at particular stages of embryo development, presented as the ratio of the observed to the expected number of live embryos $\times 100 \%$ (for the exact numbers, see Table 1). (B) The number of immature erythroid cells in livers of wild-type and cyclin $\mathrm{D} 2^{-/-}$ $\mathrm{D}^{-/-}$embryos. Values were obtained by counting the number of hematopoietic cells per field of view in hematoxylin-eosin-stained sections of E16.5 wild-type $(\mathrm{n}=4)$ and mutant livers $(\mathrm{n}=5)$. For each specimen, five independent counts were performed. Bars indicate mean values for each genotype. Error bars denote S.D. $(C)$ Histologic appearance of wildtype and mutant livers in E16.5 embryos. Paraffin sections were stained with hematoxylin and eosin. Arrows denote examples of immature erythroid cells. Note the paucity of erythroid cells in mutant livers. $(D)$ Smears of peripheral blood collected from E16.5 wild-type and cyclin $\mathrm{D} 2^{-/-} \mathrm{D}^{-/-}$embryos. Pictures were taken at the same magnification. Note the striking difference in size between wild-type and mutant erythrocytes.
These mice were much smaller than wild-type littermates (Fig. 4B). Despite being fed by liquid, calorie-rich diet, cyclin D2-only mice ultimately failed to thrive and died. This appearance of mutant mice resembles most affected cyclin D1-deficient mice (Fantl et al. 1995; Sicinski et al. 1995). We presume that combined deletion of the cyclin D1 and D3 genes exacerbates the neurologi- cal phenotype of cyclin D1-deficient mice, leading either to death within the first $24 \mathrm{~h}$ of life, or at a later stage.

Importantly, microscopic examination of organs derived from cyclin D2-only mice revealed essentially normal, unperturbed morphogenesis in all tissues analyzed. An exception to this rule was provided by the observation that cyclin $\mathrm{D} 1^{-/-} \mathrm{D} 3^{-/-}$animals displayed hypoplas-

Table 1. The survival of mutant mice

\begin{tabular}{|c|c|c|c|c|c|c|}
\hline \multirow{2}{*}{$\begin{array}{l}\text { Stage of } \\
\text { development }\end{array}$} & \multicolumn{2}{|c|}{$\mathrm{D} 1^{-/-} \mathrm{D} 2^{-/-}$} & \multicolumn{2}{|c|}{$\mathrm{D} 1^{-/-} \mathrm{D} 3^{-/-}$} & \multicolumn{2}{|c|}{$\mathrm{D} 2^{-/-} \mathrm{D} 3^{-/-}$} \\
\hline & Observed & Predicted & Observed & Predicted & Observed & Predicted \\
\hline E13.5 & $18 / 310$ & $23 / 310$ & $28 / 273$ & $31 / 273$ & $27 / 225$ & $28 / 225$ \\
\hline E16.5 & ND & ND & ND & ND & $28 / 341$ & $59 / 341$ \\
\hline E17.5 & ND & ND & ND & ND & $3 / 105$ & $11 / 105$ \\
\hline E18.5 & ND & ND & $59 / 483$ & $71 / 483$ & $2 / 144$ & $14 / 144$ \\
\hline P1 & $61 / 850$ & $73 / 850$ & $29 / 346^{a}$ & $35 / 346$ & $1 / 912^{\mathrm{b}}$ & $125 / 912$ \\
\hline P5 & $11 / 171$ & $21 / 171$ & $9 / 597$ & $88 / 597$ & - & - \\
\hline$>\mathrm{P} 10$ & $17 / 493$ & $48 / 493$ & $9 / 597$ & $88 / 597$ & - & - \\
\hline
\end{tabular}

The ratios of the number of observed viable mutants to the total number of animals analyzed (Observed) along with the expected ratios (Predicted) at different days of embryo development (E) or in postnatal life (P).

a 25 out of 29 pups died on the first day of life.

${ }^{\mathrm{b}}$ One pup found stillborn. 
Figure 4. Phenotype of cyclin D2-only (cyclin $\mathrm{D}^{-/-} \mathrm{D}^{-/-}$) mice. (A) A graph showing survival rate at particular stages of embryo (E) or postnatal (P) development calculated as the ratio of the observed to the predicted number of live embryos or pups $\times 100 \%$. For the exact numbers, see Table 1. (B) Appearance of 2-week-old wild-type and cyclin $\mathrm{D}^{-/-} \mathrm{D} 3^{-/-}$littermates. $(C-E)$ Microscopic appearance of lungs in wild-type $(C)$ and mutant $(D, E)$ 1-day-old pups. Paraffin sections were stained with hematoxylin and eosin. Note the presence of meconium in lungs of mutant animals (arrows in $D, E$ ), indicating an acute asphyxiation with the gastrointestinal content. (E) Lungs with collapsed alveoli in a dead mutant.
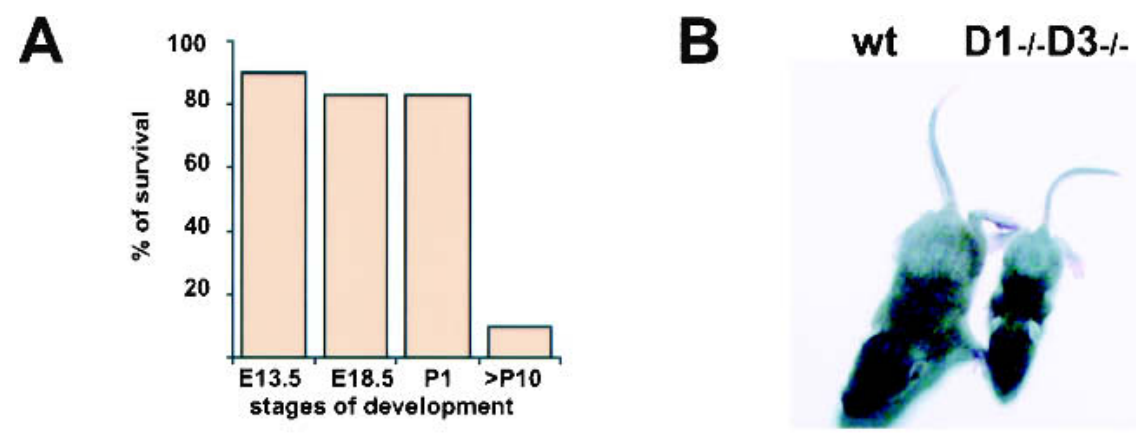

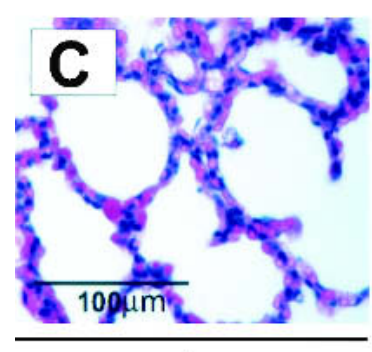

wt

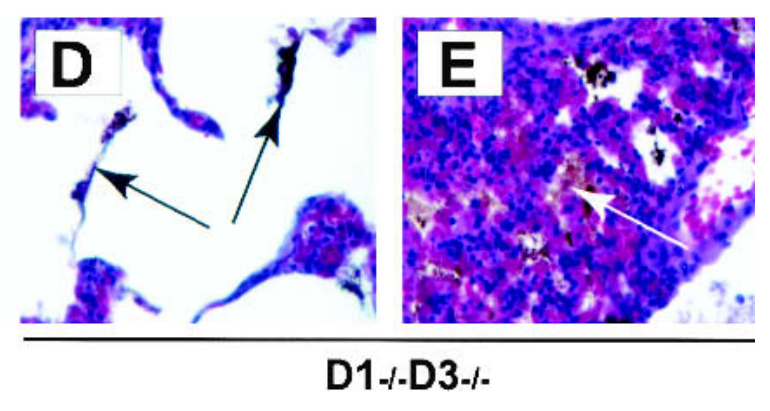

tic retinas, which closely resembled the retinas seen in cyclin $\mathrm{D}^{-/-}$mice (data not shown). Hence, cyclin D2 alone is sufficient to afford normal development in nearly all cellular compartments.

Lastly, we turned our attention to mice expressing only cyclin D3 (cyclin D1 ${ }^{-/-} \mathrm{D} 2^{-/-}$animals). These mice were born with nearly the expected Mendelian ratio (Fig. 5A; Table 1) and were initially indistinguishable from control littermates. However, by 1 wk of age it became obvious that cyclin D3-only mice displayed retarded growth and by 2 wk of age their weight was approximately one-third of that seen in wild-type littermates (2.9 g, $\mathrm{n}=6$, in cyclin $\mathrm{D} 1^{-/-} \mathrm{D} 2^{-/-}$mice vs. $7.9 \mathrm{~g}, \mathrm{n}=10$, in control mice). A neurological abnormality in cyclin D3-only mice was suggested by the observation that these mice displayed greatly impaired coordination of movements. In particular, when placed on their backs, cyclin D3-only animals had great difficulty in regaining normal body position (Fig. 5B). The impairment of movements greatly diminished the ability of mutant mice to search and to compete for food, and most likely constituted the cause of death within the first $3 \mathrm{wk}$ of life.

Histopathological examination of tissues derived from cyclin $\mathrm{D}^{-/-} \mathrm{D} 2^{-/-}$animals provided an explanation for the observed phenotype. Specifically, we found that cyclin D3-only mice lacked normally developed cerebella. As evidenced in Figure 5C and D, this organ was found only in a rudimentary form in cyclin D3-only animals, explaining their inability to move in a coordinated fashion.

Detailed histopathological analyses revealed that the number of cerebellar folia was decreased and the existing folia were stunted with shallow interfolial clefts (Fig. 5C). Moreover, the thickness of the internal granular layer, where most of the cerebellar neuronal cell bodies reside, was severely diminished, whereas Purkinje cells did not form a proper layer but were instead scattered through the molecular and internal granular layers, contributing to the hypoplastic, disorganized appearance of mutant cerebella (Fig. 5D).

In mice, the most intensive proliferation of granule neuron precursors and definitive formation of the cerebellum takes place within the first 2 postnatal weeks (Altman and Bayer 1997). We found that the phenotype of cyclin D3-only mice was obvious at postnatal day 7 (P7; data not shown), consistent with the severe impairment of neuronal precursor proliferation. Remarkably, all other tissues appeared normal in mutant mice, except for hypoplastic retinas of cyclin $\mathrm{D} 1^{-/-} \mathrm{D} 2^{-/-}$mice, which closely resembled the retinas of cyclin $\mathrm{D}^{-/-}$animals (data not shown).

\section{Molecular analyses of single-cyclin mice}

The phenotypic analyses of single-cyclin mice, described above, revealed that each of the D-cyclins is sufficient to afford nearly normal development of the vast majority of tissues. In each case, however, we found a particular cellular compartment in which a given cyclin could not support normal development, leading to circumscribed but severe abnormalities. To gain a molecular understanding of this phenomenon, we decided to initially focus on cyclin D3-only mice.

First, we analyzed the expression of D-cyclins in various organs of cyclin D3-only animals. As expected, we found a global, ubiquitous expression of this cyclin /data not shown), explaining normal development of the majority of tissues in mutant animals.

We next turned our attention to the developing cerebella, an organ where cyclin D3 failed to support normal development. Analyses of wild-type cerebella revealed that the external granule layer, where prolifera- 
A

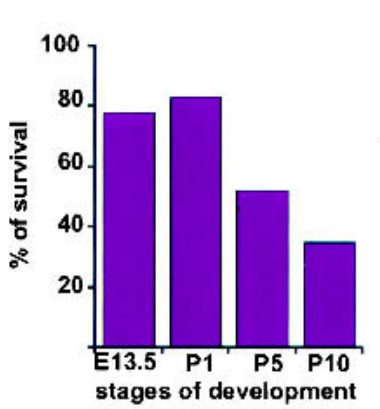

C

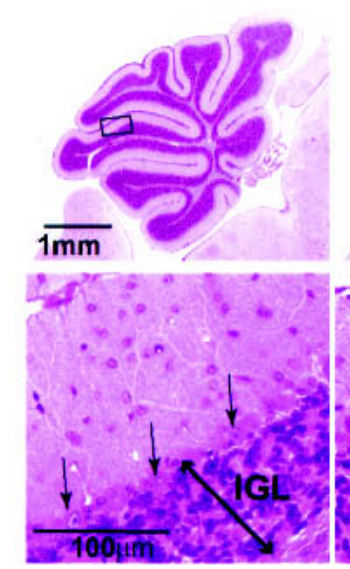

wt
B
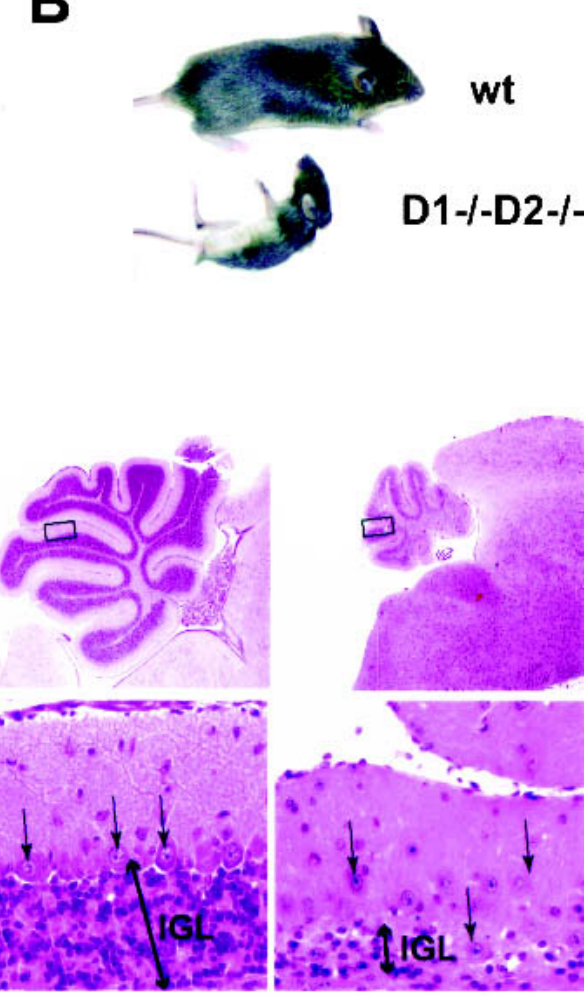

D2-I-
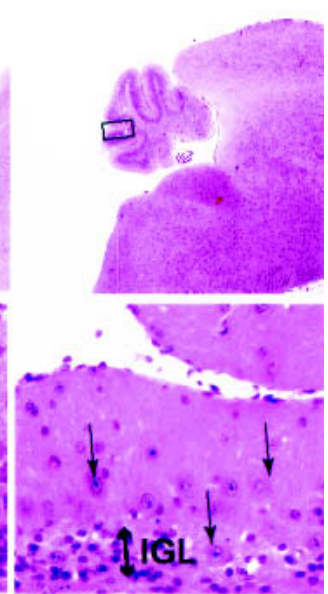

D1-/-D2-I-
Figure 5. Phenotype of cyclin D3-only (cyclin $\mathrm{D} 1^{-/-} \mathrm{D} 2^{-/-}$) mice. (A) A graph showing survival rate at particular stages of embryo (E) or postnatal (P) development calculated as the ratio of the observed to the predicted number of live embryos or pups $\times 100 \%$. For the exact numbers, see Table 1. (B) Appearance of 16-day-old wild-type and cyclin $\mathrm{D} 1^{-/-} \mathrm{D} 2^{-/-}$littermates. Mutant mice display pronounced problems with coordination of their movements. $(C)$ Paraffin sections of cerebella from 16-day-old wild-type and cyclin $\mathrm{D} 1^{-/-}$ $\mathrm{D} 2^{-/-}$mice stained with hematoxylin and eosin. Note the dramatic difference in size and the abnormal number of foliae in cyclin $\mathrm{D} 1^{-/-} \mathrm{D} 2^{-/-}$ cerebella. The cyclin D2 ${ }^{-/-}$cerebella, which were reported to display mild abnormalities in the anatomy of the foliae (Huard et al. 1999) are shown for comparison. $(D)$ Higher magnification of images shown in $C$ reveals severely reduced cell numbers within the internal granule layer (IGL) and abnormal positioning of Purkinje cells (arrows) in cyclin $\mathrm{D} 1^{-/-} \mathrm{D} 2^{-/-}$cerebella. tion of cerebellar neuronal precursors takes place (Altman and Bayer 1997), expressed high levels of cyclin D1 and D2 but very little cyclin D3 (Fig. 6A). Importantly, the corresponding layer of cyclin $\mathrm{D}^{-/-} \mathrm{D} 2^{-/-}$ mice expressed only slightly up-regulated levels of cyclin D3 (Fig. 6A). Hence, mutant granule cells fail to sufficiently up-regulate cyclin D3. This, in turn, compromises the ability of these cells to proliferate and results in a severe cerebellar hypoplasia. Consistent with this idea, we found that the proliferation rate in the external granular layer of cyclin D3-only cerebella was significantly reduced, as compared with wild-type littermates (Fig. 6B).

To further extend these analyses, we prepared protein lysates from wild-type and cyclin D3-only cerebella and we determined the extent of pRB phosphorylation, using Western blotting. We found that a significant fraction of pRB was hyperphosphorylated in wild-type cerebella. In contrast, the majority of pRB in cyclin D3-only cerebella was found in a hypophosphorylated state (Fig. 6C). We concluded that the developing cerebellar granule precursors fail to sufficiently up-regulate cyclin D3, resulting in inability to phosphorylate pRB and, consequently, to drive normal S-phase entry.

\section{$N$-myc and D-cyclins in cerebellar granule cells}

The high expression levels of cyclins D1 and D2 in the developing cerebella, together with inability of cyclin
$\mathrm{D} 1^{-/-} \mathrm{D} 2^{-/-}$cerebella to up-regulate cyclin D3, suggested to us that transcription factor(s) operating in cerebellar granule cells may impinge on the cell cycle machinery via cyclins D1 and D2 but not D3.

The identity of one candidate transcription factor was provided by the observation that conditional, neuronalspecific knockout of the N-myc gene results in a cerebellar phenotype that is strikingly similar to that seen in cyclin $\mathrm{D}^{-/-} \mathrm{D} 2^{-/-}$mice (Knoepfler et al. 2002). Consistent with these findings, N-myc, but not other members of the Myc family, is specifically expressed in the proliferating zone of the developing cerebellum (Kenney et al. 2003). These observations led us to hypothesize that the $\mathrm{N}$-myc drives proliferation of cerebellar granule neuronal precursors by impinging on cyclins D1 and D2. To test this hypothesis, we compared the expression pattern of N-myc in the developing cerebella of wild-type and cyclin $\mathrm{D}^{-/-} \mathrm{D} 2^{-/-}$mice. As expected, we found high levels of $\mathrm{N}$-myc in the external granule layer of wild-type animals (Fig. 7A); this layer also expressed high levels of cyclins D1 and D2 (Fig. 6A) and incorporated BrdU (Fig. 6B). Importantly, the corresponding layer of cyclin $\mathrm{D}^{-/-} \mathrm{D} 2^{-/-}$mice expressed equally high levels of N-myc (Fig. 7A), but only very low levels of cyclin D3 (Fig. 6A) and presented greatly reduced proliferation rate (Fig. 6B). These observations are consistent with the hypothesis that N-myc induces cyclins D1 and D2 in wild-type cerebellum, but fails to up-regulate cyclin D3 in wild-type or in mutant tissues. 
Ciemerych et al.
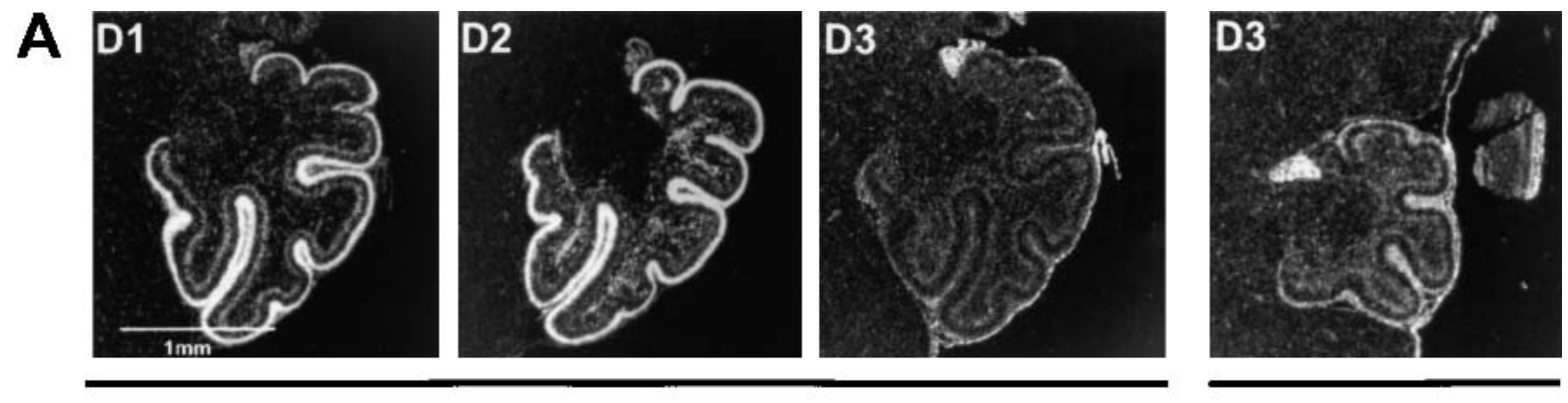

\section{wt}

D1-I-D2-1-
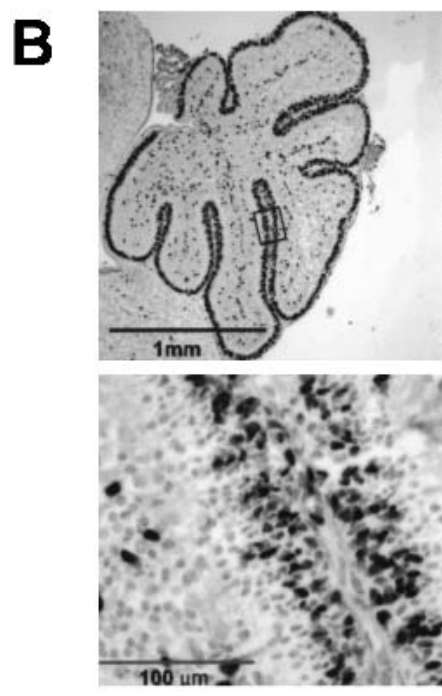

wt

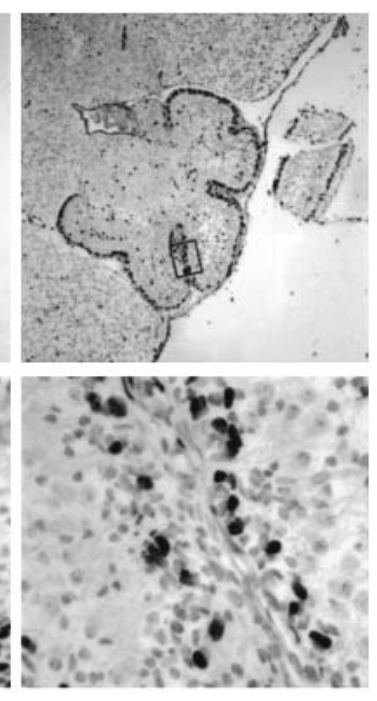

D1-/-D2-/-

Figure 6. Molecular analyses of developing cerebella. (A) Sections of cerebella from 5-day-old wild-type (wt) or cyclin D1 $1^{-/-} \mathrm{D} 2^{-/-}$ mice were hybridized with riboprobes specific for cyclin D1, D2, and D3. White color represents the hybridization signal. $(B)$ Bromodeoxyuridine (BrdU) incorporation in wild-type and $\mathrm{D} 1^{-1-} \mathrm{D} 2^{-/-}$cerebella derived from 5-day-old mice. The proliferating external granule layer of wild-type mice contains numerous BrdU positive cells, whereas these numbers are reduced in mutant tissue. (Lower panel) Higher magnification of the external granule layer. $(C)$ Protein lysates prepared from 5-day-old wild-type or mutant cerebella were probed with an antibody against the retinoblastoma protein. (ppRB) Hyperphosphorylated form of the pRB.

To test this notion directly, we derived primary cell cultures from neonatal cerebella of wild-type mice. The great majority $(>85 \%)$ of cells in these cultures correspond to granule neuronal precursors, and the system has been validated to study proliferation and differentiation of cerebellar neuronal precursors (Kenney and Rowitch 2000). Cells were infected with a retrovirus encoding N-myc, and the levels of D-cyclins were determined $48 \mathrm{~h}$ after infection using Western blotting. We found that ectopic expression of N-myc led to significant upregulation of cyclins $\mathrm{D} 1$ and $\mathrm{D} 2$. In marked contrast, the levels of cyclin D3 remained unchanged (Fig. 7B). We concluded that in cerebellar granule neuronal precursors, $\mathrm{N}$-myc communicates with the cell cycle machinery by inducing cyclins D1 and D2, but not cyclin D3. Consequently, cyclin $\mathrm{D} 1^{-/-} \mathrm{D} 2^{-/-}$mice are unable to up-regulate cyclin D3 in cerebellar granule neuronal precursors, leading to severe cerebellar hypoplasia in cyclin D3-only animals.

\section{Analyses of other compartments in single-cyclin mice}

The analyses described above indicated that the phenotype of cyclin D3-only mice can be traced to the inability of mutant cerebella to sufficiently up-regulate the remaining, intact D-cyclin. We next asked whether the same holds true for other cellular compartments that fail to develop properly in cyclin D-deficient animals. First, we focused on developing retinas, a tissue that is profoundly hypoplastic in cyclin D1-deficient mice (Fantl et al. 1995; Sicinski et al. 1995) as well as in cyclin $\mathrm{D}^{-/-}$ $\mathrm{D} 2^{-/-}$and $\mathrm{D}^{-/-} \mathrm{D}^{-/-}$mice (Fig. $8 \mathrm{~A}$; data not shown). We compared the expression pattern of D-cyclins in the retinas of wild-type versus cyclin D2-only mice using in situ 


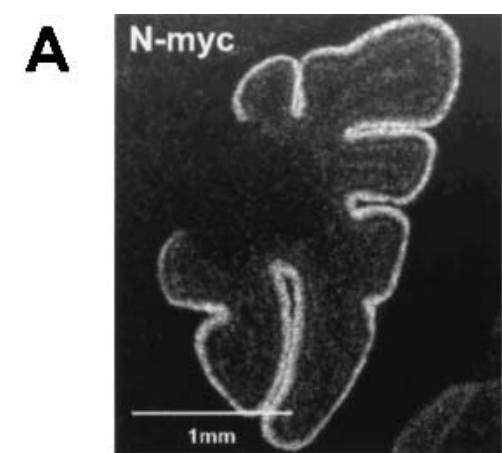

wt
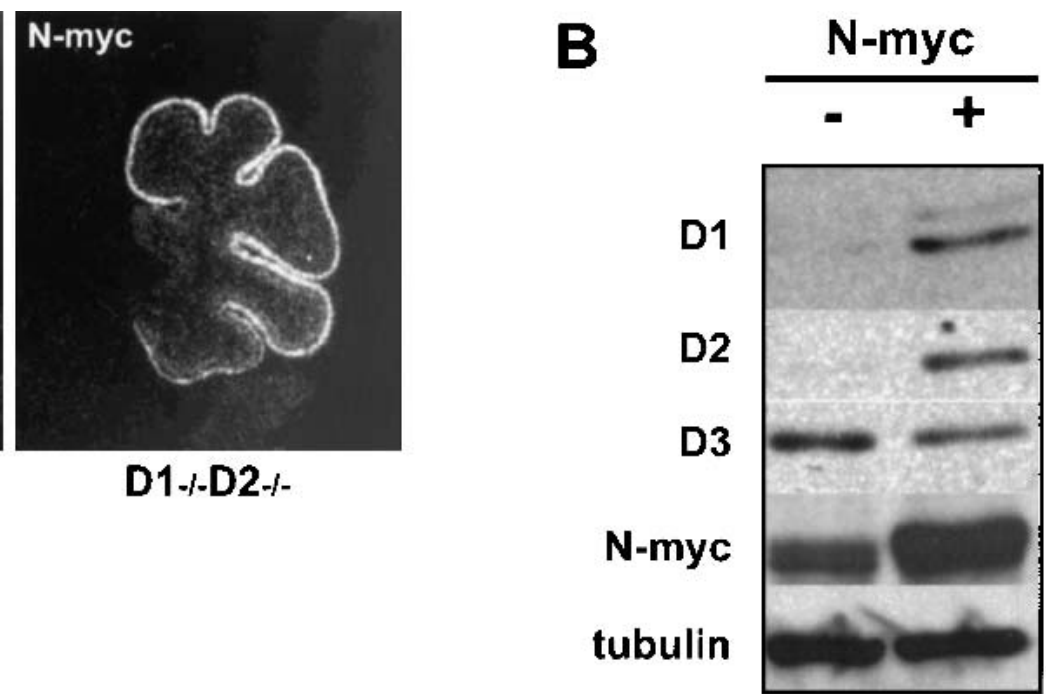

Figure 7. N-myc in the developing cerebella and in cultured cerebellar granule neuron precursors. $(A) \mathrm{N}$-myc expression in developing cerebella of 5-day-old wild-type and cyclin $\mathrm{D} 1^{-/-} \mathrm{D} 2^{-/-}$mice detected by in situ hybridization with a riboprobe specific for $\mathrm{N}$-myc. White color represents hybridization signal. $(B)$ In vitro cultured cerebellar granule neuron precursors were infected with a retrovirus encoding N-myc. The levels of cyclin D1, D2, D3, and N-myc were detected by Western blotting. Blots were probed with an anti- $\alpha$-tubulin antibody to ensure equal loading.

hybridization. Adjacent sections were stained for BrdU, to mark the proliferative layer. As reported earlier (Zhang et al. 1998; Geng et al. 1999), the proliferative zone of wild-type retinas expressed very high levels of cyclin D1 and virtually no cyclin D2. The retinas of cyclin D2-only mice lacked cyclin D1, and expressed only slightly up-regulated levels of cyclin D2 (Fig. 8A). However, the increased levels of cyclin D2 in cyclin D2-only retinas were dramatically lower than that of cyclin D1 in the wild-type retinas. Importantly, unlike cyclin D1 in wild-type retinas, which was mainly expressed within the proliferating, BrdU-positive layer, the expression of cyclin D2 in cyclin D2-only retinas was largely confined to the nonproliferating zone (Fig. 8A). Thus, as was the case with cerebellar granule cells in cyclin D3-only mice, proliferating neuroretinal precursors of cyclin D2only mice fail to sufficiently up-regulate the remaining D-cyclin, leading to a severe hypoplasia in the affected tissue.

Lastly, we turned to developing fetal livers, where the erythroid compartment is unable to develop normally in the absence of cyclins D2 and D3 (Fig. 3). We isolated cells from wild-type and cyclin D1-only E14.5 livers and stained them with Ter119 antibody to distinguish erythroid, Ter119+ cells from Ter119-negative hepatocytes. Ter $119^{+}$cells were then flow-sorted, and the levels of cyclins D3 and D1 were determined by Western blotting. These analyses revealed that wild-type Ter $119^{+}$cells expressed cyclin D3 but no cyclin D1. In contrast, erythroid cells isolated from cyclin $\mathrm{D} 2^{-/-} \mathrm{D} 3^{-/-}$mice expressed no cyclin D3, and showed no up-regulation of cyclin D1 (Fig. 8B). Hence, as was the case with singlecyclin cerebella and retinas, cyclin $\mathrm{D} 2^{-/-} \mathrm{D} 3^{-/-}$erythroid cells fail to up-regulate cyclin D1, resulting in severe hematopoietic deficiency.

\section{Discussion}

It is well established that the D-cyclins are the recipients of numerous mitogenic and oncogenic signals. An important, unresolved question is whether each of the three D-type cyclins performs unique, possibly tissue-specific roles, or the functions for these proteins are fully overlapping.

The highly orchestrated, often mutually exclusive expression pattern of the three D-cyclins during development and in adult tissues raises the possibility that the D-cyclins may perform unique functions in different cellular compartments (Tam et al. 1994; Ravnik et al. 1995; Aguzzi et al. 1996; Bartkova et al. 1998; Doglioni et al. 1998; Robker and Richards 1998; Wianny et al. 1998). This notion is further supported by the observations that ectopic expression of cyclin D1, but not D3, prevents myogenic differentiation (Rao et al. 1994; Skapek et al. 1995), whereas forced expression of cyclins D2 and D3, but not D1, blocks differentiation of granulocytes (Kato and Sherr 1993). Although the three D-cyclins show very high $(75 \%-78 \%)$ amino acid identity within the socalled cyclin-box, which mediates CDK binding, the extent of homology outside this domain is only $39 \%-47 \%$ (Inaba et al. 1992; Xiong et al. 1992). It is then possible that apart from driving the phosphorylation of the retinoblastoma protein, each of the D-cyclins may perform additional, nonredundant functions, possibly via tissuespecific interactors. Indeed, D-cyclins were shown to interact with the DMP1 transcription factor (Hirai and Sherr 1996; Inoue and Sherr 1998) as well as with the estrogen receptor (Neuman et al. 1997; Zwijsen et al. 1997).

To address the specific roles for D-cyclins in development, we and others previously generated mice lacking 

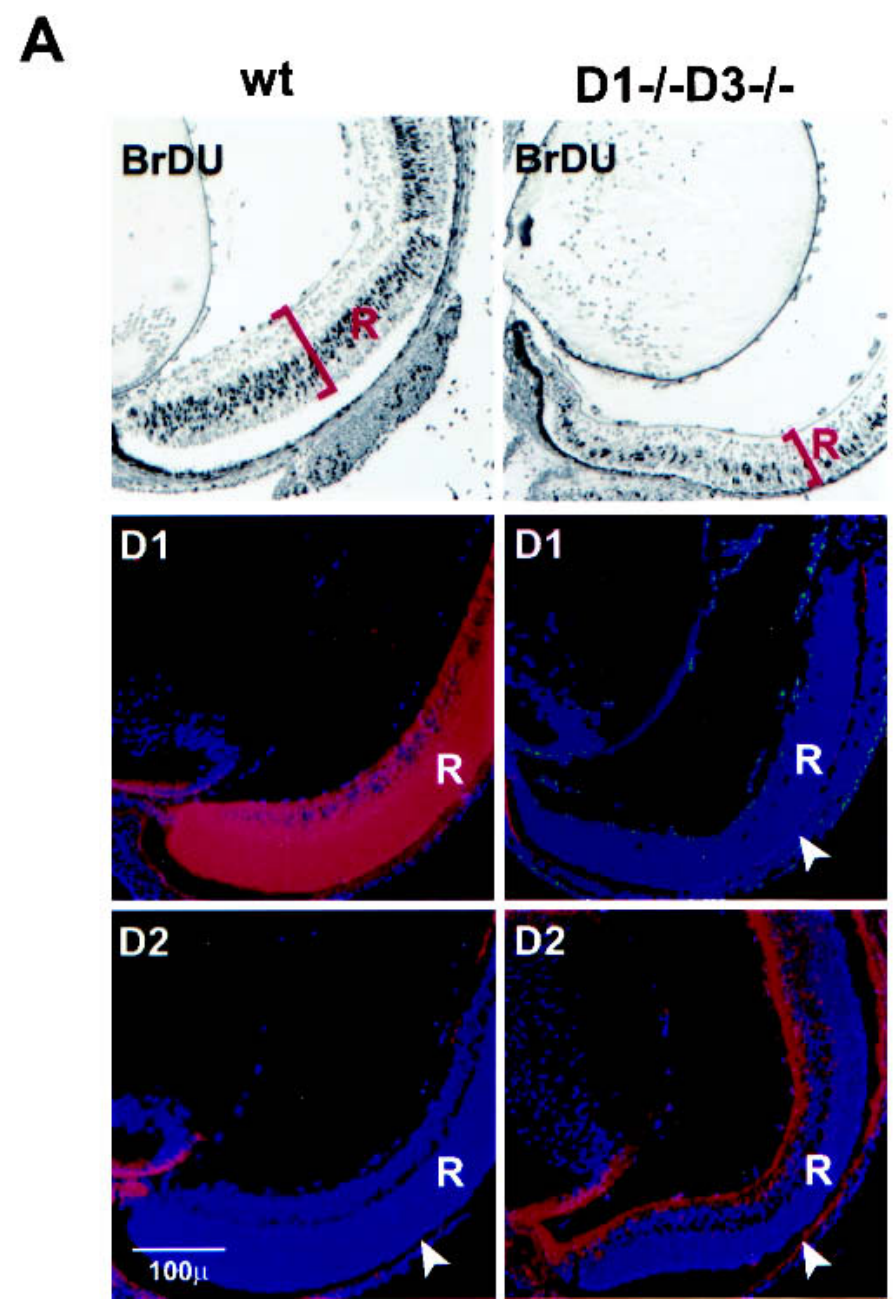

B

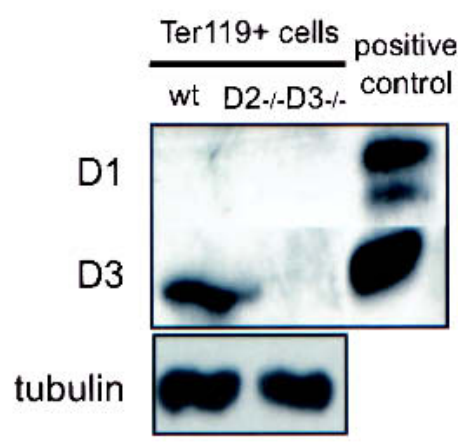

Figure 8. Analyses of mutant retinas and erythroid cells. $(A)$ BrdU incorporation and D-type cyclin expression in developing retinas at E18.5. Pregnant females were injected with BrdU, and embryonal eyes were collected after $1 \mathrm{~h}$ and processed for histology. Transcripts for cyclin D1 and D2 were detected by in situ hybridization with appropriate riboprobes. Specimens were photographed by double exposure using bright-field illumination and Hoechst epifluorescence optics. The blue color represents the Hoechst staining of cell nuclei, and the red represents the hybridization signal. $\mathrm{R}$ denotes neural part of the retina. Note that the red signal within the pigmented epithelium layer (arrowheads) represents a false positive signal that stains all probes owing to the presence of pigmented granules in these cells. $(B)$ Protein lysates were prepared from flow-sorted Ter $119^{+}$erythroid cells (derived from E14.5 embryonic livers) and then subjected to Western blotting. Blots were probed with an anti- $\alpha$-tubulin antibody to ensure equal loading. Protein extracts prepared from entire wild-type embryos were used as a positive control. each of the D-cyclin genes (Fantl et al. 1995; Sicinski et al. 1995, 1996). We found that each of these singleknockout mice displayed narrow, tissue-specific abnormalities. However, the analyses of these single-knockout mice were confounded by the presence of two remaining D-cyclins. In the present study, we reduced the complexity by generating mice that express only cyclin D1, D2, or D3. This was accomplished by crossing single-knockout mice and by generating double-knockout animals.

We expected that combined ablation of the two Dcyclin genes would lead to an early embryonic lethality. Contrary to our expectations, we found that single-cyclin mice develop normally until late gestation. Molecular analyses revealed that in mutant embryos the tissuespecific expression pattern of D-cyclins was lost, and that these embryos expressed the remaining D-cyclin in all tissues. This ubiquitous expression of cyclin D1, D2, or D3 afforded nearly normal development of all tissues. Moreover, even at later stages of life, the overwhelming majority of organs also developed without any detectable defects; cyclin D2-only and cyclin D3-only mice were born live, and a fraction of them survived until several weeks after birth. Thus, virtually normal development of many different organs can take place in the presence of a single D-cyclin. We interpret these findings as an indication that the functions for the three D-cyclins in driving development, proliferation, and differentiation of the overwhelming majority of cell types are exchangeable. An alternative explanation to be considered is that the development of some tissues may occur independently of the D-cyclins (see below).

Significantly, in each of the single-cyclin strains we found that the remaining cyclin was not able to support the development of a particular, highly selective compartment. In each case we were able to trace the phenotype to the inability of the remaining, intact D-cyclin to become up-regulated in the affected tissue. This suggests that the requirement for a particular cyclin in a given tissue is likely caused by specific transcription factors impinging on particular D-cyclins in this tissue. Indeed, our molecular analyses revealed that the $\mathrm{N}$-myc transcription factor, which seems to drive proliferation of cerebellar granule neuron precursors (Kenney et al. 2003; Knoepfler et al. 2002), can communicate with the cell cycle machinery in these cells via cyclins D1 and D2, but not $\mathrm{D} 3$, explaining the inability of cyclin $\mathrm{D} 1^{-/-} \mathrm{D} 2^{-/-}$ mice to up-regulate cyclin D3 in this tissue. Consistent 
with this idea are recent observations that conditional ablation of $\mathrm{N}$-myc in the developing cerebellum causes a profound reduction of cyclin D2 levels (the levels of cyclin D1 were not analyzed; Knoepfler et al. 2002), as well as earlier observations that another member of the Myc family, namely, c-myc, can induce cyclins D1 and D2 but not D3 in in vitro cultured murine fibroblasts (PerezRoger et al. 1999). We presume that the inability of mutant retinas and erythroid cells to sufficiently up-regulate the remaining D-cyclin can also be ascribed to a specific wiring of signal transduction pathways to the cell cycle machinery. This idea is in agreement with our earlier observations, that in mammary epithelial cells, the Ras and Neu oncogenes can communicate with the cell cycle machinery only via cyclin D1, explaining the absolute dependency of Ras- and Neu-driven oncogenic pathways on cyclin D1 (Yu et al. 2001). Hence, such rigid wiring of the signaling pathways to the core cell cycle machinery, observed in some selected tissues, offers a window of opportunity for therapeutic intervention in cancers deriving from these tissues.

Our analyses do not allow us to determine whether in these selected compartments, which rely on particular cyclins for development, the phenotypes observed in knockout mice can be solely attributed to an inability to up-regulate the remaining cyclin, or alternatively, reflect the existence of unique functions for D-cyclins. One way to conclusively address this issue is to create knock-in strains of mice in which the coding sequences for particular D-cyclins have been exchanged. These studies are in progress in our laboratory.

According to our present understanding, at least one $\mathrm{D}$-cyclin is required to afford proliferation of mammalian cells. This is based on the presence of D-cyclins in all proliferating cell types and is supported by the observations that ectopic expression of $\mathrm{p} 16^{\mathrm{INK} 4 \mathrm{a}}$ blocks proliferation of several cell types grown in vitro (Lukas et al. 1995a; Sherr and Roberts 1999). However, it was reported that embryonic stem cells do not express D-cyclins, and are not inhibited by $16^{\mathrm{INK} 4 \mathrm{a}}$ expression (Savatier et al. 1996), raising the possibility that the D-cyclin $\rightarrow p R B$ pathway may not operate in very early embryonic cycles and possibly in some other tissues of the developing embryo. For this reason, the normal development of certain compartments in single-cyclin mice might reflect the fact that the development of these tissues proceeds in a cyclin D-independent fashion. Combined ablation of the three D-cyclin genes should conclusively address this issue.

The up-regulation of the remaining, intact cyclin, observed in several tissues of mutant mice, raises the possibility of the existence of a negative feedback loop, in which the major, dominant D-cyclin normally represses the expression of other cyclins. According to this scenario, genetic ablation of the major cyclin would relieve this repression, leading to up-regulation of the remaining D-cyclins. Although this scenario is entirely plausible, we found that the molecular mechanism of cyclin reactivation operates differently in distinct tissues of mutant mice. Thus, some tissues of single-cyclin mice up-regu- late the mRNA encoding the remaining, intact cyclin, but others up-regulate the cyclin protein, without detectable changes at the RNA level (data not shown), pointing to a posttranscriptional mechanism. Hence, if such a feedback loop indeed exists, it operates through different mechanisms in various tissues. Moreover, our observation that ablation of D-cyclins leads to downregulation of $\mathrm{p} 27^{\mathrm{Kip} 1}$ raises the possibility that in addition to cross-regulating their own levels, D-cyclins may control the levels of $\mathrm{p} 27^{\mathrm{Kip} 1}$. Hence, a network of positive and negative feedback loops may exist that crossregulates the expression of D-cyclins and their interactors. Given the very frequent involvement of D-cyclins in human cancers, such networks represent potential targets for cancer therapies.

\section{Materials and methods}

Mice

Cyclin D1 $1^{-/-}, \mathrm{D} 2^{-/-}$, and $\mathrm{D} 3^{-/-}$mice (Sicinski et al. 1995, 1996; E. Sicinska and P. Sicinski, in prep.) were bred to generate double-heterozygous $\left(\mathrm{D}^{+/-} \mathrm{D} 2^{+/-}, \mathrm{D1}^{+/-} \mathrm{D} 3^{+/-}, \mathrm{D} 2^{+/-} \mathrm{D}^{+/-}\right)$and heterozygous/knockout $\left(\mathrm{D}^{+/-} \mathrm{D}^{-/-}, \mathrm{D}^{+/-} \mathrm{D}^{-/-}, \mathrm{D}^{+/-} \mathrm{D}^{-/-}\right)$ animals. These mice were then crossed, yielding $\mathrm{D} 1^{-/-} \mathrm{D} 2^{-/-}$, $\mathrm{D}^{-/-} \mathrm{D} 3^{-/-}$, and $\mathrm{D} 2^{-/-} \mathrm{D}^{-/-}$animals. Mice were genotyped by the PCR as described (Sicinski et al. 1995, 1996).

\section{BrdU staining}

Pregnant females or 5-day-old mice were injected intraperitoneally with bromodeoxyuridine (BrdU, Sigma) at $100 \mu \mathrm{g} / \mathrm{g}$ of body weight. E13.5 embryos, eyes dissected from E18.5 embryos, or postnatal cerebella were collected after $1 \mathrm{~h}$ and fixed in $4 \%$ paraformaldehyde in PBS. Five-micrometer-thick paraffin sections were stained with anti-BrdU antibody (Becton Dickinson), followed by detection with the Vectastain ABC kit (Vector Laboratories).

\section{Western blot and kinase assays}

Organs were dissected from embryos at E13.5-E18.5 or from mice at days 1 or 5 after birth (P1 or P5), and protein lysates were prepared. One-hundred micrograms of proteins was separated by $12 \%$ SDS-PAGE (or $6 \%$ for retinoblastoma protein analysis). In vitro cultured cerebellar granule precursor cells were washed in PBS, scraped into lysis buffer, and sonicated as described (Kenney and Rowitch 2000). Twenty-five micrograms of protein lysates was separated on $12.5 \%$ SDS-PAGE (or $8 \%$ for N-myc analyses) and transferred to Immobilon-P membranes (Millipore). The immunoblots were probed with the following antibodies: anti-cyclin D2 (recognizing both cyclin D1 and D2; M-20; Santa Cruz Biotechnology), anti-cyclin D3 (C-16; Santa Cruz Biotechnology), anti-p27 (C-19; Santa Cruz Biotechnology), anti-pRb (245; PharMingen), anti-N-myc (C-19; Santa Cruz), anti-actin (MAB1501, Chemicon International), or anti$\alpha$-tubulin (DM 1A, Sigma). As secondary antibodies, peroxidaseconjugated IgG (Bio-Rad) was used, followed by chemiluminescence detection.

For kinase assays, $200 \mu \mathrm{g}$ of protein lysates prepared from E13.5 embryos was incubated with anti-CDK2 antibody (M-2; Santa Cruz Biotechnology) conjugated to agarose beads. Immunoprecipitates were subjected to kinase reaction using histone $\mathrm{H1}$ as a substrate as described (Geng et al. 2001). Controls in- 
cluded preincubation of lysates in the presence of $15 \mu \mathrm{M}$ roscovitine (Calbiochem) for $4 \mathrm{~h}$, followed by immunoprecipitation with anti-CDK2 antibody (in the presence of $15 \mu \mathrm{M}$ roscovitine) as well as immunoprecipitation with an unrelated, control antibody (anti-progesterone receptor, C-19; Santa Cruz Biotechnology).

\section{Histopathologic analyses}

Embryos or organs dissected from mice were fixed in Bouin's fixative (Sigma) and embedded in paraffin. Five-micrometerthick sections were stained with hematoxylin and eosin. Peripheral blood was obtained from carotid arteries of viable E16.5 embryos. Blood smears were prepared using the wedge technique, followed by air-drying and Wright-Giemsa staining.

\section{In situ hybridization}

Eyes were collected from E18.5 embryos, and cerebella were collected from 5-day-old mice and processed as described (Sicinski et al. 1995). Sections were hybridized with $\alpha-\left[{ }^{35} S\right]$ thio-UTPlabeled riboprobes specific for cyclin D1, D2, D3, and N-myc as described (Sicinski et al. 1995).

\section{Flow-sorting of fetal livers}

Livers were dissected from E14.5 mouse embryos, and singlecell suspensions were obtained. Erythroid cells were then stained with anti-mouse Ter119 antibody (Ly-76) coupled with phycoerythrin (Pharmingen), and Ter119+ cells were sorted using a MoFlo cell sorter (Cytomation). Protein lysates were immediately prepared from sorted cells; $50 \mu \mathrm{g}$ of lysate was used for Western blot analyses.

\section{Retroviral constructs}

Mouse N-myc (Wood et al. 2000) was cloned into the pWZL retroviral vector. 293-EBNA (Invitrogen) packaging cells were cotransfected with retroviral constructs, gagpol, and vesicular stomatitis virus G glycoprotein plasmids, using Fugene 6 transfection reagent (Roche); $10 \mu \mathrm{g}$ of each plasmid was used per transfection. Packaging cells were refed $12 \mathrm{~h}$ after transfection. Retroviral supernatants were harvested every $24 \mathrm{~h}$ for $72 \mathrm{~h}$ and stored at $-80^{\circ} \mathrm{C}$ until use.

\section{In vitro culture and infection of cerebellar granule neuron} precursors

Cerebella from 4- to 5-day-old Swiss-Webster mice were dissected, and cerebellar granule cell cultures were established essentially as described (Kenney and Rowitch 2000). Briefly, cell suspensions were plated at the density $3 \times 10^{5}$ cells $/ \mathrm{cm}^{2}$ onto poly-DL-ornithine-coated plastic plates in Dulbecco's modified Eagle's medium F-12 (DMEM-F-12) containing 15 mM HEPES, L-glutamine, pyroxidine hydrochloride (GIBCO), N2 supplement (GIBCO), $10 \%$ fetal calf serum, $25 \mathrm{mM} \mathrm{KCl}$, penicillin, streptomycin, and $1.5 \mu \mathrm{g} / \mathrm{mL}$ of biologically active, unmodified $\mathrm{N}$-terminal fragment of Sonic hedgehog (Shh, Biogen Inc.). Cells were permitted to adhere during the 6-8-h period of incubation in $37^{\circ} \mathrm{C}$ at $0.5 \% \mathrm{CO}_{2}$. For $24 \mathrm{~h}$ prior to retroviral infection, cells were incubated in serum-free DMEM-F12 supplemented with 2 $\mathrm{mM} \mathrm{KCl}, \mathrm{N} 2$ supplement, antibiotics, and $3 \mu \mathrm{g} / \mathrm{mL}$ of Shh. For infections this medium was removed and saved, then cells were exposed to retroviral supernatants for $2-3 \mathrm{~h}$. Supernatants were removed, and conditioned medium was readded. Medium was supplemented with $1 \mu \mathrm{g} / \mathrm{mL}$ of cyclopamine, to inhibit the ac- tion of Shh. Control cultures were treated with noninfectious conditioned packaging cell medium. Cells were harvested $48 \mathrm{~h}$ after infection.

\section{Acknowledgments}

We thank the members of the Sicinski lab and Jola Polanowska for help and advice. The work reported in this paper was undertaken during the tenure of a Research Training Fellowship awarded by the International Agency for Research on Cancer and The Kosciuszko Foundation Fellowship to M.A.C. A.M.K. is supported by a Fellowship from The Medical Foundation, Inc. (Boston, MA). D.H.R. acknowledges the NINDS, the National Multiple Sclerosis Society, and the McDonnell Foundation for support. P.S. held a Barr New Investigator Award. The work was supported by NIH grant 1R01CA85296 and the American Cancer Society grant RPG-99-042-01-CCG (to P.S.).

The publication costs of this article were defrayed in part by payment of page charges. This article must therefore be hereby marked "advertisement" in accordance with 18 USC section 1734 solely to indicate this fact.

\section{References}

Adams, P.D. 2001. Regulation of the retinoblastoma tumor suppressor protein by cyclin/cdks. Biochim. Biophys. Acta 1471: M123-M133.

Aguzzi, A., Kiess, M., Rued D., and Hamel, P.A. 1996. Cyclins D1, D2 and D3 are expressed in distinct tissues during mouse embryogenesis. Transgenics 2: 29-39.

Altman, J. and Bayer, S.A. 1997. Development of cerebellar system in relation to its evolution, structure and functions. CRC Press, Boca Raton, FL.

Bartkova, J., Lukas, J., Strauss, M., and Bartek, J. 1998. Cyclin D3: Requirement for G1/S transition and high abundance in quiescent tissues suggest a dual role in proliferation and differentiation. Oncogene 17: 1027-1037.

Bates, S., Bonetta, L., MacAllan, D., Parry, D., Holder, A., Dickson, C., and Peters, G. 1994. CDK6 (PLSTIRE) and CDK4 (PSK-J3) are a distinct subset of the cyclin-dependent kinases that associate with cyclin D1. Oncogene 9: 71-79.

Cheng, M., Olivier, P., Diehl, J.A., Fero, M., Roussel, M.F., Roberts, J.M., and Sherr, C.J. 1999. The $\mathrm{p} 21^{\text {Cip1 }}$ and $\mathrm{p} 27^{\text {Kip } 1}$ CDK "inhibitors" are essential activators of cyclin D-dependent kinases in murine fibroblasts. EMBO J. 18: 1571-1583.

Doglioni, C., Chiarelli, C., Macri, E., Dei Tos, A.P. Meggiolaro, E., Dalla Palma, P., and Barbareschi, M. 1998. Cyclin D3 expression in normal, reactive and neoplastic tissues. I. Pathol. 185: 159-166.

Fantl, V., Stamp, G., Andrews, A., Rosewell, I., and Dickson, C. 1995. Mice lacking cyclin D1 are small and show defects in eye and mammary gland development. Genes \& Dev. 9: 2364-2372.

Geng, Y., Whoriskey, W., Park, M.Y., Bronson, R.T., Medema, R.H., Li, T., Weinberg, R.A., and Sicinski, P. 1999. Rescue of cyclin D1 deficiency by knockin cyclin E. Cell 97: 767-777.

Geng, Y., Yu, Q., Sicinska, E., Das, M., Bronson, R.T., and Sicinski, P. 2001. Deletion of the $\mathrm{p} 27^{\mathrm{Kip} 1}$ gene restores normal development in cyclin D1-deficient mice. Proc. Natl. Acad. Sci. 98: 194-199.

Greenough, A. 1995. Meconium aspiration syndrome-Prevention and treatment. Early Hum. Dev. 41: 183-192.

Hirai, H. and Sherr, C.J. 1996. Interaction of D-type cyclins with a novel myb-like transcription factor, DMP1. Mol. Cell. Biol. 
16: 6457-6467.

Huard, J.M., Forster, C.C, Carter, M.L., Sicinski, P., and Ross, M.E. 1999. Cerebellar histogenesis is disturbed in mice lacking cyclin D2. Development 126: 1927-1935.

Inaba, T., Matsushime, H., Valentine, M., Roussel, M.F., Sherr, C.J., and Look, A.T. 1992. Genomic organization, chromosomal localization, and independent expression of human cyclin D genes. Genomics 13: 565-574.

Inoue, K. and Sherr, C.J. 1998. Gene expression and cell cycle arrest mediated by transcription factor DMP1 is antagonized by D-type cyclins through a cyclin-dependent-kinase-independent mechanism. Mol. Cell. Biol. 18: 1590-1600.

Kato, J.Y. and Sherr, C.J. 1993. Inhibition of granulocyte differentiation by G1 cyclins D2 and D3 but not D1. Proc. Nat1. Acad. Sci. 90: 11513-11517.

Kenney, A.M. and Rowitch, D.H. 2000. Sonic hedgehog promotes $G_{1}$ cyclin expression and sustained cell cycle progression in mammalian neuronal precursors. Mol. Cell. Biol. 20: $9055-9067$.

Kenney, A.M., Cole, M.D., and Rowitch, D.H. 2003. Nmyc1 upregulation by Sonic hedgehog signaling promotes proliferation in developing cerebellar granule neuron precursors. Development 130: 15-28.

Kiess, M., Gill, R.M., and Hamel, P.A. 1995. Expression of the positive regulator of cell cycle progression, cyclin D3, is induced during differentiation of myoblasts into quiescent myotubes. Oncogene 10: 159-166.

Knoepfler, P.S., Cheng, P.F., and Eisenman, R.N. 2002. N-myc is essential during neurogenesis for the rapid expansion of progenitor cell populations and the inhibition of neuronal differentiation. Genes \& Dev. 16: 2699-2712.

Lam, E.W., Glassford, J., Banerji, L., Thomas, N.S., Sicinski, P., and Klaus, G.G. 2000. Cyclin D3 compensates for loss of cyclin D2 in mouse B-lymphocytes activated via the antigen receptor and CD40. J. Biol. Chem. 275: 3479-3484.

Lukas, J., Parry, D., Aagaard, L., Mann, D.J., Bartkova, J., Strauss, M., Peters, G., and Bartek, J. 1995a. Retinoblastomaprotein-dependent cell-cycle inhibition by the tumour suppressor p16. Nature 375: 503-506

Lukas, J., Bartkova, J., Welcker, M., Petersen, O.W., Peters, G., Strauss, M., and Bartek, J. 1995b. Cyclin D2 is a moderately oscillating nucleoprotein required for G1 phase progression in specific cell types. Oncogene 10: 2125-2134.

Matsushime, H., Roussel, M.F., Ashmun, R.A., and Sherr, C.J. 1991. Colony-stimulating factor 1 regulates novel cyclins during the G1 phase of the cell cycle. Cell 65: 701-713.

Matsushime, H., Ewen, M.E., Strom, D.K., Kato, J.Y., Hanks, S.K., Roussel, M.F., and Sherr, C.J. 1992. Identification and properties of an atypical catalytic subunit (p34PSK-J3/cdk4) for mammalian D type G1 cyclins. Cell 71: 323-334.

Matsushime, H., Quelle, D.E., Shurtleff, S.A., Shibuya, M., Sherr, C.J., and Kato, J.Y. 1994. D-type cyclin-dependent kinase activity in mammalian cells. Mol. Cell. Biol. 14: 2066-2076.

Meyerson, M. and Harlow, E. 1994. Identification of G1 kinase activity for cdk6, a novel cyclin D partner. Mol. Cell. Biol. 14: 2077-2086.

Neuman, E., Ladha, M.H., Lin, N., Upton, T.M., Miller, S.J., Di Renzo, J., Pestell, R.G., Hinds, P.W., Dowdy, S.F., Brown, M., et al. 1997. Cyclin D1 stimulation of estrogen receptor transcriptional activity independent of cdk4. Mol. Cell. Biol. 17: 5338-5347.

Ortega, S., Malumbres, M., and Barbacid, M. 2002. Cyclin Ddependent kinases, INK4 inhibitors and cancer. Biochim. Biophys. Acta 1602: 73-87.

Perez-Roger, I., Kim, S.H., Griffiths, B., Sewing, A., and Land, H. 1999. Cyclins D1 and D2 mediate myc-induced proliferation via sequestration of $\mathrm{p} 27(\mathrm{Kip} 1)$ and $\mathrm{p} 21(\mathrm{Cip} 1)$. EMBO $J$. 18: 5310-5320.

Rao, S.S., Chu C., and Kohtz, D.S. 1994. Ectopic expression of cyclin D1 prevents activation of gene transcription by myogenic basic helix-loop-helix regulators. Mol. Cell. Biol. 14: 5259-5267.

Ravnik, S.E., Rhee, K., and Wolgemuth, D.J. 1995. Distinct patterns of expression of the D-type cyclins during testicular development in the mouse. Dev. Genet. 16: 171-178.

Robker, R.L. and Richards, J.S. 1998. Hormone-induced proliferation and differentiation of granulosa cells: A coordinated balance of the cell cycle regulators cyclin D2 and p $27^{\text {Kip1 }}$. Mol. Endocrinol. 12: 924-940.

Savatier, P., Lapillonne, H., van Grunsven, L.A., Rudkin, B.B., and Samarut, J. 1996. Withdrawal of differentiation inhibitory activity/leukemia inhibitory factor up-regulates D-type cyclins and cyclin-dependent kinase inhibitors in mouse embryonic stem cells. Oncogene 12: 309-322.

Sherr, C.J. and Roberts, J.M. 1999. CDK inhibitors: Positive and negative regulators of G1-phase progression. Genes \& Dev. 13: $1501-1512$.

Sicinski, P., Donaher, J.L., Parker, S.B., Li, T., Fazeli, A., Gardner, H., Haslam, S.Z., Bronson, R.T., Elledge, S.J., and Weinberg, R.A. 1995. Cyclin D1 provides a link between development and oncogenesis in the retina and breast. Cell 82: 621-630.

Sicinski, P., Donaher, J.L., Geng, Y., Parker, S.B., Gardner, H., Park, M.Y., Robker, R.L., Richards, J.S., McGinnis, L.K., Biggers, J.D., et al. 1996. Cyclin D2 is an FSH-responsive gene involved in gonadal cell proliferation and oncogenesis. $\mathrm{Na}$ ture 384: 470-474.

Skapek, S.X., Rhee, J., Spicer, D.B., and Lassar, A.B. 1995. Inhibition of myogenic differentiation in proliferating myoblasts by cyclin D1-dependent kinase. Science 267: 1022-1024.

Solvason, N., Wu, W.W., Parry, D., Mahony, D., Lam, E.W., Glassford, J., Klaus, G.G., Sicinski, P., Weinberg, R., Liu, Y.J., et al. 2000. Cyclin D2 is essential for BCR-mediated proliferation and CD5 B cell development. Int. Immunol. 12: 631-638.

Tam, S.W., Theodoras, A.M., Shay, J.W., Draetta, G.F., and Pagano, M. 1994. Differential expression and regulation of cyclin D1 protein in normal and tumor human cells: Association with Cdk4 is required for cyclin D1 function in G1 progression. Oncogene 9: 2663-2674.

Tsutsui, T., Hesabi, B., Moons, D.S., Pandolfi, P.P., Hansel, K.S., Koff, A., and Kiyokawa, H. 1999. Targeted disruption of CDK4 delays cell cycle entry with enhanced p27(Kip1) activity. Mol. Cell. Biol. 19: 7011-7019.

Wianny, F., Real, F.X., Mummery, C.L., Van Rooijen, M., Lahti, J., Samarut, J., and Savatier, P. 1998. G1-phase regulators, cyclin D1, cyclin D2, and cyclin D3: Up-regulation at gastrulation and dynamic expression during neurulation. Dev. Dyn. 212: 49-62.

Wood, M.A., McMahon, S.B., and Cole M.D. 2000. An ATPase/ helicase complex is an essential cofactor for oncogenic transformation by c-Myc. Mol. Cell 5: 321-330.

Xiong, Y., Menninger, J., Beach, D., and Ward, D.C. 1992. Molecular cloning and chromosomal mapping of CCND genes encoding human D-type cyclins. Genomics 13: 575-584.

Yu, Q., Geng, Y., and Sicinski, P. 2001. Specific protection against breast cancers by cyclin D1 ablation. Nature 411: 1017-1021.

Zhang, P., Wong, C., DePinho, R.A., Harper, J.W., and Elledge, S. 1998. Cooperation between the Cdk inhibitors $\mathrm{p} 27^{\mathrm{kip} 1}$ and p5 $7^{\text {kip2 }}$ in the control of tissue growth and development. Genes \& Dev. 12: 3162-3167.

Zwijsen, R.M., Wientjens, E., Klompmaker, R., van der Sman, J., Bernards, R., and Michalides, R.J. 1997. CDK-independent activation of estrogen receptor by cyclin D1. Cell 88: 405-415. 


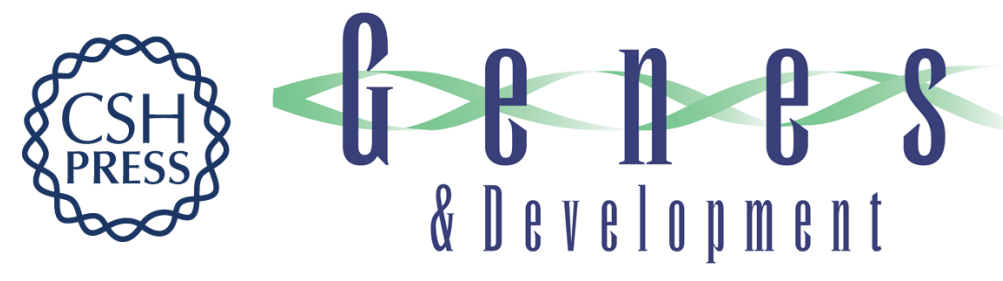

\section{Development of mice expressing a single D-type cyclin}

Maria A. Ciemerych, Anna M. Kenney, Ewa Sicinska, et al.

Genes Dev. 2002, 16:

Access the most recent version at doi:10.1101/gad.1023602

References This article cites 45 articles, 20 of which can be accessed free at: http://genesdev.cshlp.org/content/16/24/3277.full.html\#ref-list-1

License

Email Alerting Receive free email alerts when new articles cite this article - sign up in the box at the top Service right corner of the article or click here.

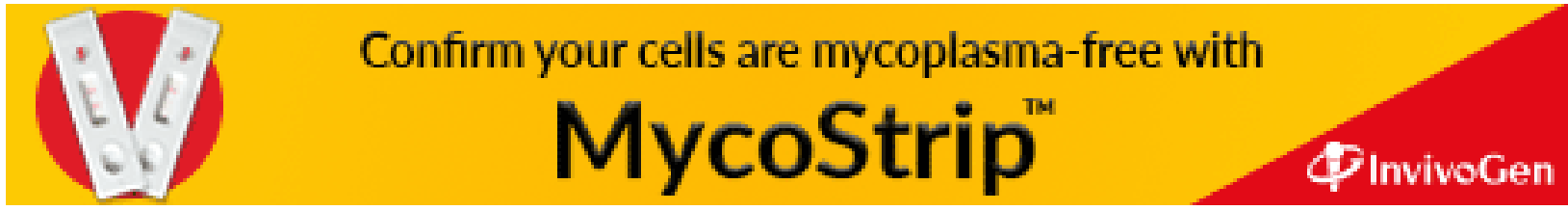

